https://helda.helsinki.fi

\title{
Pierre Nicole and amour-propre
}

\section{Tolonen, Mikko}

De Gruyter Oldenbourg

2020-08-24

Tolonen , M 2020 , Pierre Nicole and amour-propre . in H Haara , K Stapelbroek \& M Immanen (eds), Passions, Politics and the Limits of Society . , 10, Helsinki Yearbook of

Intellectual History , vol. 1, De Gruyter Oldenbourg , Berlin , pp. 195-218 . https://doi.org/10.1515/9783110679861-0

http://hdl.handle.net/10138/318658

https://doi.org/10.1515/9783110679861-012

cc_by

draft

Downloaded from Helda, University of Helsinki institutional repository.

This is an electronic reprint of the original article.

This reprint may differ from the original in pagination and typographic detail.

Please cite the original version. 


\section{Pierre Nicole and amour-propre}

Amour-propre is a central concept for understanding early-modern moral and political thought. Much attention in recent scholarship has been placed on the analysis of amour-propre in which the excessive attraction to the self (amourpropre) is distinguished from the proper love of the self (amour de soi) that can be argued to correlate with the love of God. ${ }^{1}$ This is a familiar idea of the juxtaposition between charity as a theological concept and self-love that corrupts it. Scholars are also aware that early-modern authors took different approaches to amour-propre, concupiscence, self-love and self-interest and not all of the seventeenth-century authors outright condemned human selfishness. ${ }^{2}$ Of the early-modern authors following this line of interpretation Jean-Jacques Rousseau characteristically makes a distinction between proper self-preservation (instinctual) and "excessive, and illusion-ridden attachment to the self". ${ }^{3}$ Mi-

Kari Saastamoinen inspired me to broaden my methodological approach during my doctoral studies in the mid-2000s to a closer reading of texts than what I was accustomed to at the time. It is this method of close, philosophical reading that I follow in this paper. Heikki Haara pressed me to contribute to this collection of papers for which I am now thankful. I would also like to express my gratitude to Béatrice Guion for her very helpful comments and criticism on my reading of Pierre Nicole on different occasions. I'm also grateful to Eric Schliesser, Christian Maurer and James Harris for organising workshops in the early 2010s that contributed to my thinking on Nicole.

1 For considerations of different aspects of Rousseau's conception of amour-propre, see Nicholas J. H. Dent, “Amour-propre” in his A Rousseau Dictionary (Oxford: Blackwell, 1992), 33-36 and Dent, "Rousseau on amour-propre," Supplement to the Transactions of the Aristotelian Society 72 (1998): 57-73. See also Timothy O'Hagan, "Rousseau on amour-propre: on Six Facets of amour-propre," Proceedings of the Aristotelian Society 99 (1999): 91-107 and Frederick Neuhouser, "Rousseau on the Relation between Reason and Self-Love (amour-propre)," Internationales Jahrbuch des Deutschen Idealismus 1 (2003): 221-239.

2 The 'arguments for the constructive potential of human corruption' by La Rochefoucauld, Pascal, and Nicole have been studied for example in Ben Rogers, "In Praise of Vanity: the Augustinian Analysis of the Benefits of Vice from Port-Royal to Mandeville" (PhD diss., University of Oxford, 1994).

3 Michael Moriarty, Fallen Nature, Fallen Selves: Early Modern French Thought II (Oxford University Press, 2006), 238. See also Pierre Force, Self-Interest before Adam Smith: A Genealogy of Economic Science (Cambridge University Press, 2003) and especially Béatrice Guion, "Du traité des passions à l'art de se connaître soi-même: l'écrit moral au XVII siècle," in L'Homme et ses Passions, Actes du XVII Congrès international de l'Association Guillaume Budé, eds. Isabelle Boehm, Jean-Louis Ferrary et Sylvie Franchet d'Espèrey (Paris: Les Belles Lettres, 2016), 643-654. 
chael Moriarty has shown that also Cornelius Jansen was pointing to this division and that there are also other seventeenth-century authors who did not lack conceptual tools to separate natural self-preservation from perverted attachment to self. ${ }^{4}$ The interpretation of Rousseau's role in shaping early-modern discussion of amour-propre has been particularly great. This same division between amour de soi and amour-propre has also been extended to concern Adam Smith. ${ }^{5}$ The main concept that then emerges from this analysis is of course that of interest. ${ }^{6}$ While these major figures and this approach to amour-propre have received much attention, what has not been fully exhausted is a nuanced analysis of amour-propre offered in Pierre Nicole's essays where the conceptual tool of interest is not sufficient to grasp the relevance of amour-propre. ${ }^{7}$ The argument put forward in this essay is that Nicole, as an Augustinian intellectual, formulated a theoretically significant analysis of amour-propre that can be seen to differ from the interest-centred analysis explained above that crucially anticipated eighteenth-century British thinking on civil society. ${ }^{8}$ Instead of self-interest, the main emphasis in Nicole's theory is on self-esteem and how our conception of the self is constructed in reciprocal relationship with our interlocutors. The purpose, in short, is to articulate Nicole's theory of amour-propre and to show

4 Moriarty, Fallen Nature, Fallen Selves, 171-185.

5 Force, Self-Interest before Adam Smith, 41-47. Force takes his cue from Rousseau's definition of amour-propre already in Force, "Self-Love, Identification, and the Origin of Political Economy,” Yale French Studies 92 (1997): 46-64.

6 For classic interpretation putting the emphasis particularly on interest in Jansenist understanding of amour-propre, see Marcel Raymond, "Du jansénisme à la morale de l'intrétêt," Mercure de France 1126 (1957): 238 -255. For more elaborations on interest in, see Marcel Gauchet, “De l'avènement de l'individu à la décoverte de la société”, in Annales E.S.C. 34 (1979): 451-463; Dominique Weber, "Le 'commerce d'amour-propre' selon Pierre Nicole," Astérion - Philosophie, histoire des idées, pensée politique 5 (2007): 169-196. For elaborations of the relevance of interest for eighteenth-century Britain, see Albert O. Hirschman, The Passions and the Interests (Princeton, NJ: Princeton University Press, 1977) and Malcolm Jack, Corruption and Progress: The Eighteenth-Century Debate (New York: AMS Press, 1989). For a useful further analysis of the relevance of French moralists with respect to the question of formation of modern society, see Johan Heilbron, "French Moralists and the Anthropology of the Modern Era," in The Rise of the Social Sciences and the Formation of Modernity: Conceptual Change in Context, 1750-1850, ed. Johan Heilbron, Lars Magnusson, and Björn Wittrock (Dordrecht: Springer, 1998), 77-106.

7 My interpretation is thus not intended as a critical intervention in Nicole studies, but as a contribution on the use and relevance of Nicole's essays in the eighteenth-century British context. For critical scholarship on Nicole and his essays, see Béatrice Guion, Pierre Nicole moraliste (Paris: Honoré Champion, 2002).

8 For a somewhat contrasting interpretation, see Béatrice Guion, "The Fable of the bees: proles sine matre?," in Bernard de Mandeville's Tropology of Paradoxes: Morals, Politics, Economics, and Therapy, eds. Edmundo Balsemão Pires and Joaquim Braga (Cham: Springer, 2015), 91-104. 
how Nicole constructed one of the building blocks for the architects of the Scottish Enlightenment. At the same time, Nicole deserves our attention on his own right as one of the great historical observers of human condition.

\section{Light of God and Hobbism}

Pierre Nicole's essays were mainly composed in 1670s. The first volume of them was translated into English already in 1680. John Locke compiled his own translations of three of Nicole's essays in 1675-8. By the turn of the century Nicole's essays were widely known in Britain. These essays can be interpreted in various ways. We may read them with a view to a normative doctrine, which spells out in terms of basic Christian principles of toleration, charity and respect. We may even consider Nicole's view of Christian politeness. However, Nicole's essays also include a perceptive, naturalistic analysis of civil society based on an account of the basic principles of human nature. The descriptive account may be seen as independent from the normative side of Nicole's essays. In this article, Nicole's essays are interpreted as a blueprint towards the development of political philosophy in the works of Bernard Mandeville, David Hume, Adam Smith and many others. The discussion will concentrate on this descriptive side of Nicole.

The concept of concupiscence plays a crucial role in the Augustinian moral tradition to which Pierre Nicole belongs. ${ }^{9}$ For Pierre Nicole it is a general term referring to the position of the fallen man that has left him in a direct contrast with God. Nicole's argument is geometrical in design. He claims that a man is either motivated through God or this worldly "inclination" that, in short, is a "general propensity of our corrupt nature". ${ }^{10}$ Nicole is not attempting to pin

\footnotetext{
9 I find Moriarty, Fallen nature, Fallen Selves as a useful account of Augustinian background for eighteenth-century French thinking. About Pierre Nicole, including his Augustinian background see, Edward D. James, Pierre Nicole, Jansenist and Humanist: A Study of his Thought (The Hague: Martinus Nijhoff, 1981).

10 Pierre Nicole, "Of the knowledge of one's self," in Moral essays, contain'd in several treatises on many important duties, vol. 3 (London, 1680) 4. Pierre Nicole, "De la connoissance de soimême," in Essais de morale [Document électronique]: contenus en divers traittez sur plusieurs devoirs importans, (Reprod. de l'éd. de, Paris: G. Desprez, 1701, 1997), III, 4-5. I have compared the quotes that I use with the original French text. If I modify the translation, I give the original French text in the footnote. Otherwise, I only indicate the pages to the French edition that I have used. However, for clarity's sake I have substituted most of the references to 'self-love' used in the translation with 'amour-propre', if there is no indication that Nicole in that particular point is clearly pointing at the 'self-love' side of amour-propre.
} 
down the actual concept in all its implications, but points out that all the "sentiments of concupiscence" are "contrary to the law of God and his eternal justice". ${ }^{11}$ This, however, does not imply that the outward actions motivated through these sentiments would necessarily be in conflict with God's will.

It is important to notice that concupiscence is characterised as an inclination. We are either drawn towards God or pulled away from him. Nicole explains this dichotomy by writing that in 'the bottom of the heart' we can find two separate and conflicting principles, the love of "God" and the love of "creature". ${ }^{12}$ Epistemologically the matter is simple. Either our actions are motivated through the love of God or concupiscence. Only a few live through God's grace and sincerely love God. This is possible only if God's will, placed in the heart, touches the person in a certain way, which in other words means that he has been given efficient grace. Such a person treats other people with charity. Perhaps the easiest way to understand the role of grace is to say that the ones who act through grace have God's will as their motivating principle. Their love of God "spills over" towards other people as charity. The rest are sinners. They have God's light in their heart, but it does not sensibly motivate.

The idea that the soul needs to be sensibly touched by God is important for Nicole. It is, he thinks, perfectly logical to state that God's justice is implanted in every human heart, but only a select few are effectively moved by it. The idea of being touched is important also in other respects. For example, Nicole does not have to revert to an unconvincing argument that God's light or justice would be dim or weak in some people and stronger in others. God is the truth and there cannot be any variations of it. This also explains how most of the people are motivated through another principle. Only from the "insensibility towards" God "springs" our "sensible and lively esteem for creatures". Human soul is a faculty that simply "cannot be without some inclination, and must always fix her self on some object". ${ }^{13}$ Thus, if it is not God and our love for him that moves us, it must be something else, which in Nicole's vocabulary is termed concupiscence.

11 Pierre Nicole, "A discourse, wherein is shown how dangerous conversation is," in Moral essays, contain'd in several treatises on many important duties, vol. 2 (London, 1684), 272. Nicole, "Discours où l'on fait voire combien les entretiens des hommes sont dangereux," in Essais de morale, II, 66-67.

12 Nicole, "Of the knowledge of one's self," in Moral essays, III, 118. Nicole, "De la connoissance de soi-même," in Essais de morale, III, 139-140.

13 Pierre Nicole, "Of the fear of God," in Moral essays, contain'd in several treatises on many important duties, 3rd. ed., vol. 1 (London, 1696), 83. Nicole, "De la crainte de Dieu," in Essais de morale, I, 168. 
This dichotomy is also the root of Nicole's rigorous Jansenist conception of sin. However, by constructing his theory in this way, Nicole leaves another option open. Also a sinner can be a good Christian by trying to reform the wicked state of his soul and desiring to live according to God's law. Since God's light is implanted in the soul, even when it does not sensibly motivate, everyone is able to know God's eternal law and will. In fact, not even the worst of human beings are able to escape the "penetrating rays of his justice". ${ }^{14}$ Thus, everyone who truly desires (and is capable of using the faculty of reason) is able to learn "the law", "the will" and "the order of God". ${ }^{15}$ However, for these sinners God's justice is not an intrinsic, motivating principle in the soul and it never will be if God does not change their inner constitution. These men have to strive for the truth by trying to conquer the contrasting inclination, concupiscence, which is also a naturally motivating principle of the heart. Main point of Nicole's normative doctrine is the idea that it is possible that men may consciously carry out good acts (those that God wills us to do and that are in accordance with his law and order) and lead a life of a good Christian, even when they do not have efficient grace and God's will does not efficiently move them. ${ }^{16}$

On most occasions Nicole uses concupiscence as a rather vague, general term referring to man's overall inclination to drift away from God. Amour-propre, on the other hand, directly linked to this propensity, is a faculty that is pinned down more precisely. In fact, Nicole's significance as a moral philosopher should perhaps be evaluated as an attempt to analyse this difficult concept and form a logical system of its implications.

For Nicole amour-propre is the first principle. The idea of concupiscence might remark the fact that our souls are inclined towards creatures, but it is not really towards all the creatures that we are drawn to. Nicole's way of further unravelling this inclination is with a necessary reference to amour-propre. A man is in love with himself instead of God. When describing our fallen state, Nicole remarks that 'we bring into the world with us a will totally taken up with the

14 Nicole, "Of the weakness of man," in Moral essays, I, 58. Nicole, "De la faiblesse de l'homme," in Essais de morale, I, 123.

15 Nicole, "Of the weakness of man," in Moral essays, I, 54. Nicole, "De la faiblesse de l'homme," in Essais de morale, I, 76. Nicole, "Of the means to conserve peace amongst men," in Moral essays, I, 115. Nicole, "Des moyens de conserver la paix avec les hommes," in Essais de morale, I, 232.

16 About God, grace and concupiscence see especially James, Pierre Nicole, Jansenist and $\mathrm{Hu}$ manist. 
love of itself, and incapable of loving any thing but with relation to our selves' ${ }^{17}$ A man does "not only love himself". He "loves himself without limits, and without measure; loves only himself, and refers all to himself". He simply cannot even desire anything that does not stand in a certain "relation to himself" ${ }^{18}$ It is evident that without efficient grace there is no possibility of universal benevolence, but how does Nicole's account differ from Hobbists who also claim that a man is an utterly selfish creature, naturally incapable of other-regarding affection?

Some commentators think that it does not differ at all. Pierre Force has emblematically argued that "Nicole agrees entirely with Hobbes on the description of human nature". ${ }^{19}$ I agree that there are passages in Nicole's essays that give the impression that his understanding of human nature is in accordance with what has often been taken as Hobbes's view. It is thus crucial for us to read carefully Nicole's essay of charity and self-love. Nicole argues that we have "a secret inclination to seek all things" for ourselves. A man, Nicole writes, has a natural propensity to "make himself the center of all". This principle is also characterised as 'a natural tyranny' elsewhere. ${ }^{20}$ This "tyrannical disposition" to make everything centre in us is irresistibly 'stamped in the bottom of' our "hearts". It "renders" us "violent, unjust, cruel, ambitious, flatterers, envious, insolent and quarrellous". As Nicole dramatically rounds off his argument - it is truly "a monster" that "we harbour in our bosoms". ${ }^{21}$

It might be a monster that we harbour in our breasts, but it is not a Hobbist monster. In a Hobbist system self-love engages men to hurt others is a battle for survival. We may debate whether this was Thomas Hobbes's own first principle, but we have to accept it when we talk about Hobbism. In this theory self-preservation is the beginning and the end. Nicole agrees that all our wrongdoings are caused by amour-propre. It certainly "includes the seeds of all the crimes, and of all the misdemeanors of men, from the smallest, even to the most detestable

17 Nicole, "A discourse, wherein is shown how dangerous conversation is," in Moral essays, II, 259. Nicole, "Discours où l'on fait voire combien les entretiens des hommes sont dangereux," in Essais de morale, II, 51.

18 Nicole, "Of charity and self-love," in Moral essays, III, 124. Nicole, "De la charité et de l'amour-propre," in Essais de morale, III, 147.

19 Force, Self-Interest before Adam Smith, 77.

20 Nicole, “Of Grandeur," in Moral essays, II, 194. Nicole, "De la grandeur”, Essais de morale, II, 218.

21 Nicole, "Of charity and self-love," in Moral essays, III, 124. Nicole, "De la charité et de l'amour-propre," in Essais de morale, III, 147. 
ones". ${ }^{22}$ "The love of our selves", Nicole underscores, is the "fountain of all our maladies" and it "gives us a violent inclination for pleasures, for promotion, for all that doth nourish our curiosity" and it "disposes us to procure" our "desires by all sorts of means how unjust and how criminal soever they may be". But Nicole's conception of amour-propre is something different than that of Hobbism. First of all, Nicole's idea of what causes us to revert to unjust means is not a struggle to preserve ourselves no matter what. The only reason why our worldly inclinations are so violent is that by centring everything to ourselves we are desperately trying "to fill up" that "terrible vacuity which the loss of our true happiness hath caused in our hearts". ${ }^{23}$

This wretched state of the soul is the characteristic feature of a fallen man. A man cannot "bear the interior reproach" of his "disorder". ${ }^{24}$ He does not become aware of his disorder by a conscious process, but feels it ever since the day he is born and thus "inclines continually to fly from himself". It is because of this desperate misery of not being touched by God that we revert to means that are unjust and criminal. "A man without grace" is such "a great punishment to himself" that he "looks" even "upon himself in some sort as his own great enemy". ${ }^{25}$ We are unconsciously trying to put ourselves in God's place. Inevitably Nicole thinks that this is an uphill battle. The urge to succeed is so violent that without outward restrictions we might turn to any means necessary. Simultaneously, man's miserable life is uncontrollably swayed by "violent passions" that "spring from an unknown root" and "proceed from a hidden abyss". ${ }^{26}$ Nicole does not understand the prevalence of amour-propre as mere self-preservation. He is constructing his theory from different perspective. Meanwhile, he has no problem of using and modifying Hobbes's ideas.

When we understand the foundation of Nicole's point of view, another vital aspect of amour-propre becomes comprehensible. The inherent need to centre everything around ourselves is called a tyrannical propensity for a reason. The simplest and most primitive way of trying to fill up the emptiness of our soul is to

22 Nicole, "Of charity and self-love," in Moral essays, III, 124-5. Nicole, "De la charité et de l'amour-propre," in Essais de morale, III, 147.

23 Nicole, "Of the knowledge of one’s self," in Moral essays, III, 64. Nicole, "De la connoissance de soi-même," in Essais de morale, III, 76.

24 Nicole, "Of the weakness of man," in Moral essays, I, 59. Nicole, "De la faiblesse de l'homme," in Essais de morale, I, 124.

25 Nicole, "Of the knowledge of one's self," in Moral essays, III, 4. Nicole, "De la connoissance de soi-même," in Essais de morale, III, 4.

26 Nicole, "Of the fear of God," in Moral essays, I, 80. Nicole, "De la crainte de Dieu," in Essais de morale, I, 163. 
"dominate over" the "fellow-travellers in the same unfortunate road". ${ }^{27}$ A fallen man is never fully cured of this instinctive quality and all men "inevitably" have an inclination "of domineering and lording over" other "men". ${ }^{28}$ This desire manifests itself in all the possible aspects of life. A particularly strong feature of human nature is a "desire of domineering over the minds of others". ${ }^{29}$ Once a man has obtained some opinion, he is "naturally wedded to" it. Not necessarily because it would be a token of particularly good judgment, but because he is "never free from a desire of lording it over others by all ways possible". ${ }^{30}$

It is clear that the simplest and most inevitable function of amour-propre is to covet "sovereignty". Once we are "regarded and looked upon by others as great and powerful" and "we stir up in the hearts of others motions of respect and submission", this grossly supports our secret design to put our own image in the place of God's. ${ }^{31}$ This is the part of amour-propre that is traditionally described as self-love and derived from Hobbes's account that is couched to material goods and self-preservation. Like Hobbes, Nicole claims that in a society where there is no government, "every one would be master, and tyrannize over others". In this state it would be "a necessity" that "the stronger become lords, whilst the weak remain subject". ${ }^{32}$ Pierre Force is correct when he writes that Nicole agrees with Hobbes about the origin of government. ${ }^{33}$ Indeed, in his key-essay, Of charity and self-love, Nicole follows Hobbes's description of the origin of the government closely. But in order to understand Nicole's argument we have to see what he is doing when he agrees with Hobbes. Nicole's idea is to modify the Hobbist conception of amour-propre. In this particular essay he retains parts of Hobbes's account while his concrete point is to criticise the actual theory.

27 Nicole, "A discourse of the necessity of not trusting the conduct of ones life to chance, and of not guiding it by the rules of fancy," in Moral essays, II, 134. Nicole, "Discours sur la necessité de se nepas conduire du hazard, et par des regles de fantaisie," in Essais de morale, II, 22.

28 Nicole, "Of charity and self-love," in Moral essays, III, 133. Nicole, "De la charité et de l'amour-propre," in Essais de morale, III, 157.

29 Nicole, "Of the means to conserve peace amongst men," in Moral essays, I, 116. Nicole, "Des moyens de conserver la paix avec les hommes," in Essais de morale, I, 233.

30 Nicole, "Of the means to conserve peace amongst men," in Moral essays, I, 114. Nicole, "Des moyens de conserver la paix avec les hommes," in Essais de morale, I, 232.

31 Nicole, "Of charity and self-love," in Moral essays, III, 131-132. Nicole, "De la charité et de l'amour-propre," in Essais de morale, III, 156.

32 Nicole, "A discourse of the necessity of not trusting the conduct of ones life to chance, and of not guiding it by the rules of fancy," in Moral essays, II, 147. Nicole, "Discours sur la necessité de se nepas conduire du hazard, et par des regles de fantaisie," in Essais de morale, II, 162.

33 Force, Self-Interest before Adam Smith, 76-78. 
If the idea is to "represent" the "disposition of the hearts of men" towards "one another" in the hypothetical state of nature, we may plausibly state that it is, of course, a "condition of war" and "each man is naturally an enemy to all other men". ${ }^{34}$ Nicole carries on in this Hobbist mean. The only way that the "multitude of people", who "only endeavour the ruin of one another", can be rendered into "societies, commonwealths, and kingdoms" is when amour-propre "which is the cause of this war" changes its ways and eventually guides people how to "live in peace". A man "loves domination". He "loves to enslave all the world to it", but he "loves yet more life and convenientness, and an easie life more than domination; and sees clearly that others are no ways disposed to suffer themselves to be domineered over". ${ }^{35}$ Once men realise the "impossibility of succeeding by force" in their tyrannical designs, they are obliged "to submit ones self to the care of his own preservation" by uniting with other men. "To strengthen this union, laws are made, and punishments ordered for those who violate them. Thus by means of tortures, and gibbets set up in publick, the thoughts and tyrannical designs of every particular mans self-love are withheld". It is indeed true, Nicole thinks, that "fear of death is then the first tye of civil society, and the first check of self-love". ${ }^{36}$

Consequently, after a government and laws have been enforced, the way that self-love side of amour-propre operates and our bid for power changes. Since "open violence" is "excluded" from men's options, they "seek other ways" to win the worldly contest. They "substitute craft for force”. When men can no longer keep on "tyrannizing over" others, they have no other option but "to content the self-love of those whom they" need. ${ }^{37}$ This is a clear expression of the Hobbist idea how justice and self-interested commerce come into the world. The idea is still to overpower everyone else and beat others in the competition of gathering supplies needed for self-preservation. It is not, Nicole reminds his audience, that 'this tyrannical inclination which makes us have a desire to rule and govern by force over others' would be lost after a government and laws have been instal-

34 Nicole, "Of charity and self-love," in Moral essays, III, 125. Nicole, "De la charité et de l'amour-propre," in Essais de morale, III, 149.

35 Nicole, "Of charity and self-love," in Moral essays, III, 126. Nicole, "De la charité et de l'amour-propre," in Essais de morale, III, 150.

36 Nicole, "Of charity and self-love," in Moral essays, III, 126. Nicole, "De la charité et de l'amour-propre," in Essais de morale, III, 150.

37 Nicole, "Of charity and self-love," in Moral essays, III, 127. I have retained the use of self-love in this particular quote, because Nicole is pointing to this side of amour-propre instead of talking about the broader concept in general. Nicole, "De la charité et de l'amour-propre," in Essais de morale, III, 152. 
led. It is still "lively in the hearts of men". In his darker moments Nicole even hints that men are merely "forced to dissemble it, until they are strengthened by gaining others by sweet ways, to have afterwards the means to bring them to their bent by force". ${ }^{38}$ Thus, the only thing that actually has changed concerning the self-love side of amour-propre is that means are different and now we have laws and justice that restrict how men act. Obviously the greatest restraint on men is the fear of "the punishment, which the laws threaten to those who have recourse to violent ways". ${ }^{39}$ Consequently, since men are "forced" to "obey the laws", they at least momentarily "forget these vast thoughts of domination" because it is "so impossible" for "them to prosper therein". ${ }^{40}$

Self-interest and commerce replace the physical struggle concerning the selflove side of amour-propre in a political society. Pierre Nicole is very specific in his description of this interested commerce. He uses the terms "utilities", "interests”, "gifts”, “mon[e]y”, "labours”, “toyls”, “services”, “real goods”, “merchandises", "traffick", "trade", and "commerce" when describing interested commerce. According to Nicole, even the exchange of civilities can be seen as part of this interested commerce, if the idea is that for "vain complacencies we obtain effective commodities". ${ }^{41}$ It is indeed "by the means and help of this commerce, all necessaries for this life are in some sort supplied for". ${ }^{42}$ However, what I find interesting is that for Nicole this self-love side of amour-propre is something that has to be accounted for before getting to the actual point he is making in Of charity and self-love -essay and what is truly interesting about amour-propre.

\section{Self-Love and Pride}

As we have seen, up to this point everything seems to be in agreement with a common perception of a Hobbist account of the origin of civil society. But all of a sudden, a rapid change takes place in Nicole's argument in his essay of

38 Nicole, "Of charity and self-love," in Moral essays, III, 129. Nicole, "De la charité et de l'amour-propre," in Essais de morale, III, 153.

39 Nicole, "Of charity and self-love," in Moral essays, III, 130. Nicole, "De la charité et de l'amour-propre," in Essais de morale, III, 154.

40 Nicole, "Of charity and self-love," in Moral essays, III, 127. Nicole, "De la charité et de l'amour-propre," in Essais de morale, III, 151.

41 Nicole, "Of charity and self-love," in Moral essays, III, 128. Nicole, "De la charité et de l'amour-propre," in Essais de morale, III, 152.

42 Nicole, "Of charity and self-love," in Moral essays, III, 127. Nicole, "De la charité et de l'amour-propre," in Essais de morale, III, 152-153. 
charity and self-love. After saying all this about laws, justice, self-love and interested commerce, Nicole is quick to point out there are "many people", whose "inclination of making themselves be beloved is stronger than that of domineering and lording over men". Thus, we haven't yet said enough about amour-propre. It is only now that Nicole starts to develop an original part of his analysis. The previous observation is the key to Nicole's moral philosophy. Nicole's argument is that amour-propre has two different sides - the self-love side, which in the Hobbist theory is more or less accounted for, and another side, which has been forgotten. This theoretical distinction is once more geometrical in design. The self-love side of amour-propre makes us want "to be rich and powerful", but this inclination is often overshadowed by another side of amour-propre, which takes into consideration the "judgements" of others and makes us avoid their "hatred and aversion". ${ }^{43}$ Like self-love, this is a universal propensity and there is not a human being that would "not desire to be loved" and take "great pleasure" when others are "turned towards them" and look favourably upon them. ${ }^{44}$

When examined from this perspective it turns out that Nicole's attitude towards Hobbism and the self-love side of amour-propre is in fact uninspired. Nicole freely borrows the idea of the origin of government from Hobbes. He runs fast through it in order to get to his actual point. As an observer of human condition, Nicole is generally fascinated by the idea that we are often completely unaware whether our motives are sincere or not. However, in the case of self-love side of amour-propre we often "easily" distinguish "what we do, either through human fear or through gross interest". ${ }^{45}$ In other words, there is no real intellectual challenge here for Nicole. The matter is completely "different regarding the subtlety of the love and esteem for men". ${ }^{46}$

This distinction between two different sides of amour-propre leads Nicole into a theoretical conclusion about civil society. Because of this division in amour-propre, according to Nicole, there are three attributes that ultimately render the existence of civil society possible. Two of these seem to be directly borrowed from Hobbes. First, amour-propre hinders us "through fear of chastise-

43 Nicole, "Of charity and self-love," in Moral essays, III, 133. Nicole, "De la charité et de l'amour-propre," in Essais de morale, III, 157.

44 Nicole, "Of charity and self-love," in Moral essays, III, 132. Nicole, "De la charité et de l'amour-propre," in Essais de morale, III, 157.

45 Nicole, "Of charity and self-love," in Moral essays, III, 135: "absolute interest”. Nicole, "De la charité et de l'amour-propre," in Essais de morale, III, 160 'un interêt grossier'.

46 Nicole, "Of charity and self-love," in Moral essays, III, 135: "it is not”... "the same of love, and esteem for men”, Nicole, “De la charité et de l'amour-propre,” in Essais de morale, III, 160 “il n' en est pas de même de la recherche de l' amour et de l' estime des hommes”. 
ment" and death "to violate the laws" and removes us "by this means outwardly from all the crimes". Second, amour-propre "comforts the necessities of others" in "the sight of" man's own "proper interest" (thus, the idea of justice and interested commerce). These two principles, in Nicole's understanding, are the quintessence of Hobbes's conception of self-love. But Nicole's point is that in human life "there are many occasions, where neither fear nor interest have any place". ${ }^{47}$ Therefore we additionally need to take into consideration a third feature of amour-propre to form a coherent theory of it. "The most general" passion that "springs from amour-propre" is "the desire of being loved" that Hobbes did not take into consideration. ${ }^{48}$ Nicole's insight is that "there is hardly any action" that we would take in order to "please God", "whereunto amour-propre cannot engage us to please men".49 Out of these three principles it is the third, the inclination that renders us to please others, that is the most effective in upholding civil society. As a feature of amour-propre it is "much more extended than the two others". ${ }^{0}$ This is the core of Nicole's redefinition of amour-propre and his criticism of Hobbism. If the idea is to form a theory of civil society based on human nature and this third feature is missing from our definition of amourpropre, it is unsurprising that civility and politeness are not an integral part of the Hobbist understanding of civil science. Simultaneously, it becomes overtly clear that theoretically politeness has little to do with interested commerce.

The reason why "we desire to be belov'd", Nicole emphasises, is "that we may love our selves more". The sole object of this propensity is to support the good opinion that we have of ourselves. "The love which others bear us makes us judge we deserve to be belov'd, and makes us frame of our selves a more lovely idea". ${ }^{11}$ For Nicole, people's approval is "the object of our vanity" and "the nourishment of amour-propre". But in fact, Nicole highlights, it is even more than this. It is "the bed or couch whereon our weakness rests", he underlines in Of charity and self-love. The same idea is expressed also in Of Christian civility. Our opinion of ourselves is laid on such a vulnerable ground that "it

47 Nicole, "Of charity and self-love," in Moral essays, III, 135. Nicole, "De la charité et de l'amour-propre," in Essais de morale, III, 160.

48 Nicole, "Of charity and self-love," in Moral essays, III, 133. Nicole, "De la charité et de l'amour-propre," in Essais de morale, III, 158.

49 Nicole, "Of charity and self-love," in Moral essays, III, 134. Nicole, "De la charité et de l'amour-propre," in Essais de morale, III, 159.

50 Nicole, "Of charity and self-love," in Moral essays, III, 134-5. Nicole, "De la charité et de l'amour-propre," in Essais de morale, III, 160.

51 Nicole, "Of charity and self-love," in Moral essays, II, 233. Nicole, "De la charité et de l'amour-propre," in Essais de morale, II, 126. 
cannot sustain it self without being under-propt by the approbation and love of others". 52

Nicole's more nuanced understanding of amour-propre becomes inevitable when we broaden our reading of his essays beyond of charity and self-love. All human beings, except perhaps the ones who have efficient grace, are proud and vain to some extent and eager to entertain a good opinion of themselves. It is unquestionably a token of vanity if we love ourselves instead of God. On several occasions Nicole calls attention to the fact that this self-liking side of amourpropre is directly linked to what is commonly called pride. "Pride", Nicole in one of his essays defines, is "a swelling of the heart, by which man dilates and magnifies himself in his own imaginations". Men have an inherent inclination to overvalue themselves, which "imprints" them with fantastic ideas of "strength", "greatness" and "excellence". ${ }^{33}$ The only reason why we additionally so passionately "desire" the "approbation of others" is that when we acquire it "we are settl'd and fortifi'd in the idea we have of our own excellence". It simply persuades us that "we are not mistaken in the opinion we have of our selves". ${ }^{4}$ It is the "greatest pleasure of a proud man" to "contemplate the idea which he makes of himself", which "is the origin of all his vain satisfactions". In human mind practically everything is related to this idea of self and for a proud man "nothing pleaseth him but in proportion as it contributes to puff it up, to adorn it, and to render it more lively". ${ }^{55}$ In brief, when "the world looks on us with esteem", we "settle in us a better opinion of our selves". ${ }^{56}$ By and large, "the true end and aim of the ambitious and voluptuous man, is but to underprop and hold up his weakness by some externe support". 57

Inevitably, since the approbation of others is "so necessary to keep up our hearts", "we are naturally inclin'd to seek and procure it". ${ }^{58}$ Human weakness

52 Nicole, “Of Christian civility," in Moral essays, II, 233-4. Nicole, "De la charité et de l'amourpropre," in Essais de morale, II, 127.

53 Nicole, "Of the weakness of man," in Moral essays, I, 1. Nicole, "De la faiblesse de l'homme," in Essais de morale, I, 1.

54 Nicole, "Of the weakness of man," in Moral essays, I, 2-3. Nicole, "De la faiblesse de l'homme," in Essais de morale, I, 4.

55 Nicole, "Of the knowledge of one's self," in Moral essays, III, 5. Nicole, "De la connoissance de soi-même," in Essais de morale, III, 6.

56 Nicole, "Of Christian civility," in Moral essays, II, 238. Nicole, "De la civilite Chrétienne," in Essais de morale, II, 131.

57 Nicole, "Of the weakness of man," in Moral essays, I, 33. Nicole, "De la faiblesse de l'homme," in Essais de morale, I, 69.

58 Nicole, "Of Christian civility," in Moral essays, II, 234. Nicole, "De la civilite Chrétienne," in Essais de morale, II, 127. 
might perhaps not be anything to rejoice at, but when judged from the perspective that underlines social cohesion in a secular world, the attitude seems to be much more ambivalent. There is indeed a positive, natural effect of the fact that "we must be flattered and caressed like children to be kept in a good humour" or "in our fashion we fall a crying, as children do in theirs". ${ }^{99}$ It is only from the supposition of our weakness that Nicole may conclude that "there is hardly" anything that makes a stronger "impression upon the mind" than "the fear of mens judgements" that "springs only from vanity". ${ }^{60}$ It is the insecurity of the opinion of ourselves (for Nicole a human being is always an insignificant being, thus this insecurity is always apparent) that makes us desirous of other people's approval, which in turn renders us sociable.

\section{Path to Politeness}

Nicole reminds his audience in several essays that men have a natural desire to boast their pride and expose it for the world to see. "There is", he writes, "a pleasure in hearing amour-propre speak when it is not disguised at all". ${ }^{61}$ In fact, "every one" has "a desire either to disparage others, or to distinguish himself from them". ${ }^{62}$ The implication is, of course, that since everyone is affected through these very same drives, amour-propre takes a different route.

Nicole calls attention to the fact that we are unable to fully understand the workings of our own amour-propre because it cunningly deceives us, yet we are extremely sharp "when we perceive it" somewhere else. In others it "appears" to us "under its natural form, and we hate it by so much more as we love our selves". But why do we hate it? Simply because of the fact that amour-propre of "other men opposes all" our own "desires". ${ }^{63}$ Consequently, this has a direct impact on the development of civil society. Once men have been living in a society for some time, everyone becomes perfectly sensible that he is not the only

59 Nicole, "Of the weakness of man," in Moral essays, I, 26. Nicole, "De la faiblesse de l'homme," in Essais de morale, I, 55.

60 Nicole, "Of charity and self-love," in Moral essays, III, 173. Nicole, "De la charité et de l'amour-propre," in Essais de morale, III, 206-207.

$\mathbf{6 1}$ Nicole, "Of the knowledge of one's self," in Moral essays, III, 10. Nicole, "De la connoissance de soi-même," in Essais de morale, III, 12.

62 Nicole, "Of the knowledge of one's self," in Moral essays, III, 2. Nicole, "De la connoissance de soi-même," in Essais de morale, III, 2-3.

63 Nicole, "Of charity and self-love," in Moral essays, III, 125. Nicole, "De la charité et de l'amour-propre," in Essais de morale, III, 148. 
one that has the urge to speak freely and to express the sentiments of the esteem that he has for himself. Men learn that "nothing” draws as much "aversion" as this inclination. Amour-propre simply "cannot shew it self without exciting it". Men "are not able to suffer" pride when they "discover it". Thus, "it is easie" for them to "judge" that the case will not be any different when others discover their true sentiments. ${ }^{64}$ It is this experience of the world that "inclines those who are sensible of the hatred of men" to try "not to expose themselves thereunto". As a result, they withdraw their amour-propre "from the sight of others", they "start to disguise and counterfeit it" and from henceforth they never "shew it under its natural shape". The method is simply 'to imitate the behaviour of those who would be intirely exempt from it'. ${ }^{65}$ These might be somewhat common notions in seventeenth-century France, but it is Nicole's original contribution to moral philosophy that he shows us how the rules of good-breeding and politeness are derived from the self-liking side of amour-propre - in a parallel way as laws and justice are derived from the self-love side of amour-propre.

The core of politeness is simply that pride should not be visible. It is "this suppression of amour-propre", Nicole stresses, "which makes human civility". 66 Politeness is "but a kind of traffick" of the self-liking side of amour-propre, "wherein we endeavour to" lure "the affection of others by owing a kindness for them". ${ }^{67}$ We may easily point out from this quote the connotations to commerce and trade, but we have to be careful not to make the mistake of assuming that there would be some kind of material interest involved in the trafficking of the self-liking side of amour-propre. In human civility there are no gross interests involved. Indeed, Nicole wants to point out the analogy between interested commerce (that is the way self-love side of amour-propre functions in civil society) and reciprocal nature of politeness. However, he is even more eager to keep these two different institutions apart. There is a good reason why useful and agreeable are separate concepts. Of course, material interest and cupidity can motivate individuals to behave politely, but as we saw earlier, in Nicole's theory

64 Nicole, "Of charity and self-love," in Moral essays, III, 135. Nicole, "De la charité et de l'amour-propre," in Essais de morale, III, 161.

65 Nicole, "Of charity and self-love," in Moral essays, III, 136. Nicole, "De la charité et de l'amour-propre," in Essais de morale, III, 161-162.

66 Nicole, "Of charity and self-love," in Moral essays, III, 136. Nicole, "De la charité et de l'amour-propre," in Essais de morale, III, 162. 'l' honnêteté humaine'. The idea is also to be found in Pascal's Thoughts, to which Nicole also refers to. I would like to thank Béatrice Guion for pointing this out.

67 Nicole, "Of Christian civility," in Moral essays, II, 234-235. Nicole, "De la civilite Chrétienne," in Essais de morale, II, 127. 
this kind of behaviour falls under the realm of interested commerce and selflove, not humane civility and self-liking. If you flatter a person in order to get some money from him, your behaviour is part of the interested commerce (that Nicole looks down with contempt). If you flatter the same person, so that he would approve your character and you may entertain a better opinion about yourself, this is humane civility (towards which Nicole's attitude is much more ambivalent). In practice, it might perhaps be impossible to keep these two spheres from overlapping, but theoretically it is important for Nicole that they are not confused as the same institution.

Nicole also demonstrates how politeness keeps evolving. He points out that "these demonstrations of affection for the most part are false". They "run into excess" and "we make a shew of more love than we have". In fact, "in the room of real love, we substitute a language full of affection". ${ }^{68}$ Plainly put, the "discourses of civility", which are "so ordinary in the mouths of men" are far apart "from the sentiments of their heart". ${ }^{69}$

But if the development brings about a custom of flattery and insincerity, moreover, men will soon learn to "keep themselves generally to a distance from all that seems vanity". Hence, the tolerable appearance of "modesty" comes into the world. ${ }^{70}$ In fact, "civility" does not merely make men to dissimulate and smooth the appearance of their "base vain glories" (which they actually are so eager to show). Since men in general are so "extremely subtile in discovering the by-ways which may be taken to make manifest in us what we desire to shew", "civility renounces these small crafts, and studies to avoid them". Simultaneously, a new fashion comes about and, at least in theory, soon there is nothing "more simple and humble" than the "discourses" of the world. Because of the nature of amour-propre, it is rendered "a general rule" that a man is "never to speak of himself". If he is forced to make a comment on himself, it has to be done "with more coldness and indifferency than of others". ${ }^{71}$ However, this does not mean that men who have adopted this new fashion would actually be humble. As Nicole points out, "pride" is "born with man" and

68 Nicole, “Of Christian civility," in Moral essays, II, 235. Nicole, "De la civilite Chrétienne," in Essais de morale, II, 127.

69 Nicole, "Of Christian civility," in Moral essays, II, 235. Nicole, "De la civilite Chrétienne," in Essais de morale, II, 128.

70 Nicole, "Of charity and self-love," in Moral essays, III, 138. Nicole, "De la charité et de l'amour-propre," in Essais de morale, III, 164.

71 Nicole, "Of charity and self-love," in Moral essays, III, 139. Nicole, "De la charité et de l'amour-propre," in Essais de morale, III, 165. 
it "never abandons him". Therefore, "in the conduct" that seems humble we may often find "a more cunning and delicate sentiment of this pride". ${ }^{72}$

It goes without saying that Nicole's normative position is different from his naturalistic description of politeness. However, I have no interest in the attempt to show Nicole's conception of Christian civility. Additionally, the actual methods how to operate politeness (or laws that protect self-love) and the locus where they are practised are of no concern. The relevant part is to examine the theoretical foundation behind (in Humean terms) artificial moral institutions and how they are derived from human nature. "It is manifest", Nicole clearly points out, that all 'conduct', which falls under the institution of politeness, is in the end aiming "directly" at the self-liking side of "amour-propre", since the idea is to "obtain the esteem of the friendship of men". ${ }^{73}$ In my opinion, what is crucial for Nicole is this link between the moral institution and the passion (self-liking side of amour-propre) and the idea that this is analogous to justice and the self-love side of amour-propre.

\section{Search for Truth, Melancholy and Progress}

Interesting fact is that even when Nicole stresses that the expressions of civility are exaggerated and often false, yet the institution compels us "to praise voluntarily what is praise-worthy, to set a value as great as we can on other mens good qualities, and not to refuse even to our enemies our testimonies of esteem which they deserve". If we fail to follow these obvious guidelines, we are very unlikely to meet with approbation from others. We also have to remember that men are not merely judged by single instances but by the overall impression of their character. Nicole goes so far as to claim that "an extreme indulgence for other mens faults", hiding and excusing them as much as possible, "never" condemning anyone, explicating "all to the best", being "easily satisfied" and rather being "deceived" than giving "way to suspicions which are hurtful" to others are all part of civility. For Nicole "all this tends directly" in the end "to amour-propre". ${ }^{74}$ Perhaps Nicole is right that this is the only way that amour-propre actually "hin-

72 Nicole, "Of charity and self-love," in Moral essays, III, 141. Nicole, "De la charité et de l'amour-propre," in Essais de morale, III, 167.

73 Nicole, "Of charity and self-love," in Moral essays, III, 150. Nicole, "De la charité et de l'amour-propre," in Essais de morale, III, 179.

74 Nicole, "Of charity and self-love," in Moral essays, III, 157. Nicole, "De la charité et de l'amour-propre," in Essais de morale, III, 187. 
ders us for passing for proud and presumptuous". ${ }^{75}$ At least, if we take Nicole's word for it, it seems that in order to even uphold our self-esteem it takes much more than an empty shell to actually "prosper in the design of making our selves beloved", to "acquire friends", "pacifie our enemies" and to "keep a good correspondence with all the world". ${ }^{76}$

Nicole does not think that a man ever succeeds in his forlorn battle of loving himself as he ought to love God. Our high "opinions" about ourselves "are grounded only upon a voluntary error". For Nicole, it really does not matter what we have achieved in the world. The opinions about ourselves "are never firm and sure", but "always mixed with mistrust, and consequently with melancholy, trouble and molestation". Instead of "pure joy" and "full and entire satisfaction which amour-propre aimeth at, all it can do" is "to suspend for some time the sentiments of sadness, which are nourished at the bottom of the heart" ${ }^{77}$ Nicolean man is pathetic, but it is difficult to imagine a civil society more progressive than the one inhabited by these men.

The idea of God's justice and order imprinted in men is a basic Christian doctrine, uninteresting as such. However, Nicole is effectively using it also as part of his naturalistic account of civil society. I think that because of this paradoxical contrast between the love of God and the love of self, the dynamic nature of Nicole's explanation of human progress appears almost modern. It is the agonising conflict within every individual, who leads a secular life that keeps the world in motion. Men are always in a genuine search after what they can think true and good. According to Nicole, every human being has to believe, at least in some very confused and obscure manner, that what he does and what he is, ultimately is worthwhile. Nicole is very precise that "we can love nothing which we do not think good" and "true". ${ }^{78}$ We "cannot" even "enjoy" anything, if we think that it is "false". ${ }^{79}$ Thus, even when stirred by base motives and false judgement, "people" have to "justifie in themselves and flatter themselves, that their stubbornness, and their inflexibility in their sentiments, proceed only from the love

75 Nicole, "Of charity and self-love," in Moral essays, III, 158. Nicole, "De la charité et de l'amour-propre," in Essais de morale, III, 189.

76 Nicole, "Of charity and self-love," in Moral essays, III, 156-7. Nicole, "De la charité et de l'amour-propre," in Essais de morale, III, 187.

77 Nicole, "Of the knowledge of one’s self," in Moral essays, III, 26. Nicole, "De la connoissance de soi-même," in Essais de morale, III, 29.

78 Nicole, "Of the knowledge of one’s self," in Moral essays, III, 31. Nicole, "De la connoissance de soi-même," in Essais de morale, III, 35.

79 Nicole, "Of the knowledge of one's self," in Moral essays, III, 30. Nicole, "De la connoissance de soi-même," in Essais de morale, III, 35. 
they have for truth". ${ }^{80}$ They "are so fashion'd by nature, that they lay hold on nothing but what is by the understanding presented to them under the appearance of some good". 81

What, of course, happens is that this seemingly noble quality turns upside down. "The love of truth" is hailed as the first principle by everybody, but it usually unveils as an ill-servant because "the chief and principal use we make" of it "is to persuade us that what we love is true". As it often unfolds, we do not "love" things "because they are true", but "we believe them true, because we love them". Thus, we manage "to add" the "idea of truth" into our "inclinations", which only fixes us "more firmly" in our meaningless ways. ${ }^{82}$ It might seem that in this manner Nicole drains the meaning of our love of truth, but he does not do so entirely. It becomes apparent that "men would not be men, did they not run after some true, or false light”. ${ }^{83}$

If men always have to justify to themselves that they are looking for something that is good and true, it is equally natural that they think that ultimately they are in search of harmony. The "life of a true Christian", Nicole writes, would be "a life of peace", but the life of a man driven by his concupiscence is a constant motion searching for peace that he cannot find. God's will is "immoveable" and "the bent and inclination of a virtuous man is towards silence as much as possible he can". ${ }^{84}$ The inclination of the common sinner is "to fly from himself" believing that 'his happiness consists in being forgetful of himself, and running headlong into this forgetfulness' ${ }^{85}$

As mistaken as they might be, men are genuinely and naturally aiming for the satisfaction that is not to be found Nicole underlines in his essay of the knowledge of one's self. The scenario is further complicated by the fact that even when men are constantly turning their eyes away from themselves, they

80 Nicole, "Of the knowledge of one's self," in Moral essays, III, 108. Nicole, "De la connoissance de soi-même," in Essais de morale, III, 128.

81 Nicole, "A discourse of the necessity of not trusting the conduct of ones life to chance, and of not guiding it by the rules of fancy," in Moral essays, II, 122. Nicole, "Discours sur la necessité de se nepas conduire du hazard, et par des regles de fantaisie," in Essais de morale, II, 7.

82 Nicole, "Of the knowledge of one's self," in Moral essays, III, 30. Nicole, "De la connoissance de soi-même," in Essais de morale, III, 35.

83 Nicole, "A discourse of the necessity of not trusting the conduct of ones life to chance, and of not guiding it by the rules of fancy," in Moral essays, II, 122. Nicole, "Discours sur la necessité de se nepas conduire du hazard, et par des regles de fantaisie," in Essais de morale, II, 7.

84 Nicole, "Of submissions to the will of God," in Moral essays, I, 76. Nicole, "De la soumission à la volonté de Dieu,” in Essais de morale, I, 158.

85 Nicole, "Of the knowledge of one's self," in Moral essays, III, 4. Nicole, "De la connoissance de soi-même," in Essais de morale, III, 4. 
have a natural desire to think that they are doing the very opposite. A Nicolean man is truly a paradox. We have "two inclinations". "One", which "makes us to fly" from ourselves, and "the other", which makes us "to seek the knowledge of our selves". They are both "natural" and "spring" from "the same fountain". ${ }^{86}$ Knowing and not knowing ourselves is difficult. A "vain" man, sooner or later, "will" always "see" his meaningless and worthless self. ${ }^{87}$ "Truth always makes it self a little light through all those clouds wherewith men strive to obscure it". Once amour-propre is at the brink of acquiring satisfaction, there are "always some rays" that come and "incommode pride"and "trouble" the "false quiet which it endeavours to procure it self". ${ }^{88}$ Naturally, a man "avoids seeing” his actual state, "because being vain he is not able to suffer the sight of his faults and miseries". "To accord these two contrary desires" a man has to be extremely astute to find "means" that are "worthy his vanity" and "satisfy" both of these inclinations "at the same time". It truly takes "craft or subtility" from the Nicolean man to be able to "cover all his faults" and "only to include' to "the image which he" forms "of himself" those "qualities which may raise him in his own thoughts" ${ }^{89}$ It is interesting that Pierre Nicole puts so much effort to show that a man has to genuinely succeed in deceiving himself (not merely other people) and believe that he is as worthy as he would like to think. Of the knowledge of one's self is a timely intervention on the human condition.

Meanwhile, what happens is that these Nicolean men are constantly forced to "renew the idea of their me". It is "this idea" of self that causes "their pleasure during their fortune" and "their displeasure during their disgrace". ${ }^{90}$ Once the former ground where men had placed the idea of their own excellence (or virtue) crumbles down - as it always does - they have to find some new ground where they can build it anew or at least support the old foundation. They are in constant motion and renewing the idea of self. There is "no other end" than "amour-propre" for their "actions", but ultimately what is directing these actions is the need to "joyn always to the idea that they have of themselves, new orna-

86 Nicole, "Of the knowledge of one's self," in Moral essays, III, 5. Nicole, "De la connoissance de soi-même," in Essais de morale, III, 6.

87 Nicole, "Of the knowledge of one's self," in Moral essays, III, 6. Nicole, "De la connoissance de soi-même," in Essais de morale, III, 7.

88 Nicole, "Of the knowledge of one's self," in Moral essays, III, 25. Nicole, "De la connoissance de soi-même," in Essais de morale, III, 29.

89 Nicole, "Of the knowledge of one's self," in Moral essays, III, 6. Nicole, "De la connoissance de soi-même," in Essais de morale, III, 7.

90 Nicole, "Of the knowledge of one's self," in Moral essays, III, 9. Nicole, "De la connoissance de soi-même,” in Essais de morale, III, 10. 
ments and new titles". ${ }^{91}$ Nicole's explanation of the cause of human progress is admirable. The idea is that 'our vanity remains' only "half satisfied" - at best. ${ }^{92}$ Thus, our whole personal identity becomes dependent upon movement. We are, at least in some sense, continuously refining and progressing, but only because there is no end to it. There is no goal and no true satisfaction that we can achieve in this world. If the motion ceases we simply cannot bear ourselves. The only way that our love for ourselves is supported is by "leaning to a number of petty supports" and we need an innumerable amount of these "little props and helps" to "keep it in repose". ${ }^{93}$ But once we come to realise (as we sooner or later always do) that the old supports were not enough to fully satisfy our vanity, we have to start looking for some new ones and the circle continues. "It is" only "by continual changes the soul maintains it self in a condition it can away with, and that it hinders it self from being overwhelmed with grief and melancholy”. Nicole's dramatic summary is that "the soul subsists only by art". ${ }^{94}$ Thus, we manage to create a vicious circle that is not completely tinted off track, because we have to genuinely believe that what we are looking for is true and good and we are also fully dependent on the opinion and approval of others. Life is but a postponement of melancholy and sadness. Yet, men keep on searching and refining their petty little ways. Meanwhile, bridges are built, fashions change and hats come off. In short, at least all the necessities of life are supplied for and conversations are more or less agreeable.

Without the idea that the truth and God are implanted in us, Nicole's scheme would go astray. Even when we are constantly fooling ourselves and desperately renewing the image we have of ourselves, we need to be able to believe that the things we love are actually good and real - that we are true and good. A man would not be a man if he did not think that he is searching for the truth. But if you are not looking from the right place, Nicole in his normative doctrine lectures, you will never find it. Your vanity will always remain, at best, half-satisfied. However, the choice that Nicole has to offer does not look too appealing for the common sinner. In fact, a fallen man is not too willing to look for inner peace, because the price to pay is too high. It would take too much to ac-

91 Nicole, "Of the knowledge of one’s self," in Moral essays, III, 8. Nicole, "De la connoissance de soi-même," in Essais de morale, III, 9.

92 Nicole, "Of the knowledge of one’s self," in Moral essays, III, 17. Nicole, "De la connoissance de soi-même," in Essais de morale, III, 19.

93 Nicole, "Of the weakness of man," in Moral essays, I, 28. Nicole, "De la faiblesse de l'homme," in Essais de morale, I, 59.

94 Nicole, "Of the weakness of man," in Moral essays, I, 29. Nicole, "De la faiblesse de l'homme," in Essais de morale, I, 61. 
cept his worthlessness. Even the idea of facing the fact that he is not as great or virtuous as he would like to be shuns him. Thus, more often than not, people keep trying to satisfy their self-liking, time and again, using their able imagination to think of different ways how to achieve the impossible.

\section{Conclusion}

Pierre Nicole has received attention from modern scholars because he is one of the first early-modern authors to outline the idea how a secular society can be rendered peaceful based on enlightened self-interest. ${ }^{95}$ "One may say truly", Nicole writes, "that absolutely to reform the world, that's to say to banish all the vices", all you need to do is "to give every one an enlightened amour-propre" [amour-propre éclairé]. Such a "society" might be "corrupt" inside, but "there would be nothing better ordered, more civil, more just, more peaceable, more honest, more generous" and, significantly, more "admirable" than this. The reason why this society would be admirable, according to Nicole, is that even when nothing but amour-propre would move it, amour-propre "would not appear there" at all. ${ }^{96}$

This idea of "amour-propre éclairé" has usually been understood in the narrow Hobbist sense as "enlightened self-interest". ${ }^{97}$ If anything, we have to take into consideration both sides of Nicole's conception of amour-propre and put a strong emphasis on the self-liking, instead of self-love, since this is Nicole's theoretical invention. Even when "true interests" are certainly involved in this society, curiously the self-liking side, which is the crux of Nicole's line of reasoning, has partly escaped modern scholars. To summarise my argument, it is both justice and politeness that have to be accounted for if we want to talk about Nicole's

95 On this point see particularly Dale Van Kley, "Pierre Nicole, Jansenism, and the Morality of Enlightened Self-Interest”, in Anticipations of the Enlightenment in England, France and Germany, ed. A. C. Kors and Paul Korshin (Philadelphia: University of Pennsylvania Press, 1987), 69-85.

96 Nicole, "Of charity and self-love," in Moral essays, III, 165. Nicole, "De la charité et de l'amour-propre," in Essais de morale, III, 197.

97 See however, Van Kley, "Pierre Nicole, Jansenism, and the Morality of Enlightened Self-Interest," 69-85, which implicitly points out that Nicole is adding something to Hobbes's account, but which however does not bring out the clear and apparent theoretical framework that is Nicole's actual contribution to Enlightenment thought. The overall question is not whether enlightened self-interest is pointed out as morally good, as Van Kley seems to think. The question is what do we mean by amour-propre éclairé in the first place and how do we derive moral institutions from amour-propre. 
idea of enlightened amour-propre. ${ }^{98}$ And for Nicole, it is the idea of the self-liking side of amour-propre that plays the foundational role in rendering a secular society tolerable.

The idea that two moral institutions, justice and politeness, (both derived from amour-propre) are needed to render a society enlightened follows consistently throughout Nicole's essays. As he clearly points out, "we owe some things to our neighbour by certain laws of justice; which are properly call'd laws". Analogously, we owe him some other things "by the bare laws of civility". Even when these laws of civility are not laws in the strict sense of the word, "the obligation" to follow them "springs from a consent amongst men" who have agreed "to blame such as shall be defective in them". Ultimately, it is "men" who "have established all these laws". ${ }^{99}$ Based on "justice" and the "motion of interest" men can "expect" certain "duties from us". It is exactly "the same" that "happens in the duties of civility". Just like in our debts, if we "are wanting" in civility, "others are effectively offended". 100

By and large, it is the rules of "civility" (not honesty, as the anonymous English translator repeatedly suggests) and "justice" that are needed in civil society. ${ }^{101}$ As

98 In other words, Nicole anticipates what I have argued about Mandeville and Hume in Tolonen, Mandeville and Hume: Anatomists of Civil Society (Oxford: SVEC, 2013).

99 Nicole, "Of the means to conserve peace amongst men," in Moral essays, I, 141. Nicole, "Des moyens de conserver la paix avec les hommes," in Essais de morale, I, 282.

100 Nicole, "Of the means to conserve peace amongst men," in Moral essays, I, 143. Nicole, "Des moyens de conserver la paix avec les hommes," in Essais de morale, I, 285-286.

101 Nicole, "Of the remedy against suspicion," in Moral essays, III, 315. Nicole, "De la guérison des soupçons," in Essais de morale, III, 315: 'lès regles de l' honnêté et de la justice'. Nicole is consistently using this parallel between civility and justice in his essays when he is discussing the principle moral institutions. Yet, the English translation repeatedly mistakes honesty for civility. Cf. Nicole, "Of reports," in Moral essays, III, 268 'those who are wanting in what may lawfully be expected from them, do undoubtedly wrong honesty [sic!] and justice, and 'tis enough to judge them guilty of infidelity' Nicole, “Des rapports," in Essais de morale, III, 322 'ceux qui manquent à ce qu' on peut attendre legitimement d' eux, blessent sans doute l' honnêteté et la justice, et il suffit pour les juger coupables d' infidelité'. And Nicole, "Of the remedy against suspicion,” in Moral essays, III, p. 317 'they may observe in this point, in respect of others, what honesty [sic!], charity, and justice demands of us.' Nicole, "De la guérison des soupçons," in Essais de morale, III, 317 'garder sur ce point à l' égard des autres ce que l' honnêteté, la charité et la justice demandent de nous.' Keohane has pointed out that when talking about 'the idea of l'Honnête' in 'the last half of the senteenth century in France' the word 'honesty is surely the wrong English word to use here' and instead 'the best terms' for 'capturing the meaning of l'honnêté' are 'civility, politeness' and 'propriety'. Keohane, Philosophy and state in France, 283-284. It is interesting that the translator of Nicole's essays was making this precise mistake and thus this mistake in English was deeply rooted already in the seventeenth century. According to Rogers, "In Praise of Vanity," 1994, the best study of the many on 
Nicole describes, "men are link'd together by an infinite number of wants". Thus, they are obliged "out of necessity to live in society" since "each particular" is not "able to subsist without others". Now, it is obvious that this implies different kinds of interests and commerce. However, what Nicole particularly wants to stress is that "for keeping up society amongst men", it is of "absolute necessity" that "they should respect and love one another". As always, Nicole wants to specifically point out that in this moral institution there are no interests or money involved. "There are a number", he writes, "of small matters" which are "highly necessary for life". People should realise that they "are bestowed gratis" and never "to be sold" because they "can only be had for love". It is precisely the fact that the "society" is "compos'd of men full of love and esteem for themselves" that special "care" has to be taken "reciprocally to please and humour one another". If not, "it would prove a loose company", "ill pleas'd and dissatisfied amongst themselves" and, in the end, not able to "continue united". Logically, "since this mutual love and esteem appears not outwardly, they have thought convenient to establish amongst themselves certain devoirs, which should be so many tokens of respect and affection". Thus, it is the institution of politeness that is of importance in the concept of "enlightened amour-propre". ${ }^{102}$

Only when we take into account that Nicole's broad definition of amourpropre has two different sides may we understand how he thinks that a secular civil society is able to function. My argument is that this forms the blueprint for Bernard Mandeville, David Hume and Adam Smith who follow Nicole's path in this overall distinction. ${ }^{103}$ They all take their cue for their political philosophy from the idea that we may derive justice and politeness from human nature, namely from the two different sides of amour-propre. Of course, Mandeville, Hume and Smith seriously modify the description of civil society by paying close attention to natural and artificial moral qualities and the evolutionary nature of moral institutions in the conjectural history of civil society. However, it was Pierre Nicole who first outlined the overall blueprint for this project that still plays a mediated role in some of our conceptions of the relationship between human nature and civil society.

honnêté is Jean-Pierre Dens, Honnête homme et la critique du goût: Esthétique et société au XVII siècle (Lexington: French Forum, 1981).

102 Nicole, "Of the means to conserve peace amongst men," in Moral essays, I, 144-145. Nicole, "Des moyens de conserver la paix avec les hommes," in Essais de morale, I, 288.

103 I've advanced this reading of Adam Smith in the Mandevillean context, for example, in Mikko Tolonen, "Pride and moral fitness in the sceptical sentimentalism of Mandeville, Hume and Smith" (paper presented at Inclusion and Exclusion in the History of Ideas Conference of the Helsinki Centre for Intellectual History, Helsinki, December 14-15, 2017). 